\title{
Advances in Parasitology
}

\section{Volumes 17 and 18}

Organized and edited by W. H. R. Lumsden, R. Muller and J. R. Baker Volume 17: 1979, xii + 416pp., E23.20 (UK on/y)/\$53.00, 0.12.031717.6

Contents

E. A. Meyer and S. Radulescu: Giardia and giardiasis. D. Zwart and D. W. Brocklesby: Babesiosis: non-specific resistance, immunological factors and pathogenesis. L. P. Joyner and J. Donnelly: The epidemiology of babesial infections. James $\mathbf{C}$. Chubb: Seasonal occurrence of helminths in freshwater fishes: part II - trematoda. Thomas A. Miller: Hookworm infections in man. Indices.

Volume 18: July 1980, xii + 364pp., E21.00 (UK only) $1 \$ 48.50 .0 .12 .031718 .4$

Contents

James C. Chubb: Seasonal occurrence of helminths in freshwater fishes: part III. larval cestoda and nematoda. G. S. Coleman: Rumen ciliate protozoa. W. C. Gibson, T. F. de C. Marshall and D. G. Godfrey: Numerical analysis of enzyme polymorphism: a new approach to the epidemiology and taxonomy of the subgenus trypanzoon. Z. Brener: Immunity to trypanosoma cruzi. P. Willadsen: Immunity to ticks. K. C. Binnington and D. H. Kemp: Role of tick salivary glands in feeding and disease transmission.
Academic Press
A Subsidiary of Harcourt Brace Jovanovich. Publishers London New York Toronto Sydney San Francisco 24-28 Oval Road, London NW1 7DX, England 111 Fifth Avenue, New York, NY 10003, USA 


\section{EVOLUTIONARY BIOLOGY OF PARASITES}

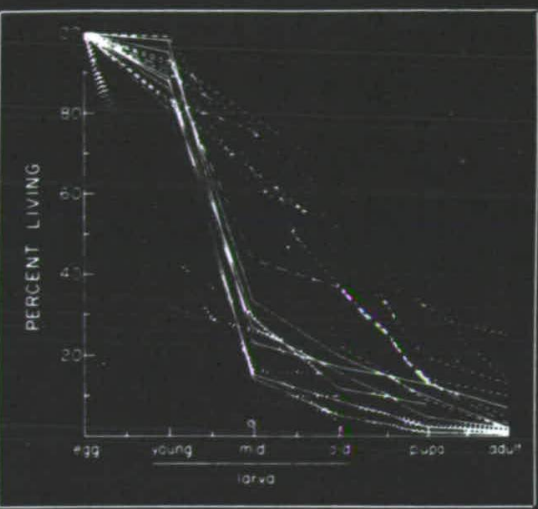

PETER W. PRICE In spite of the fact that parasites represent more than half of all living species of plants and animals, their role in the evolution of life on earth has been substantially underestimated. Here, for the first time within an evolutionary and ecological framework, Peter Price integrates the biological attributes that characterize parasites ranging from such diverse groups as viruses, bacteria, protozoa, and fungi, to helminths, mites, insects, and parasitic flowering plants.

Cloth, \$17.50/£9.70. Paper, \$6.95/£3.80. Monographs in Population Biology, 15

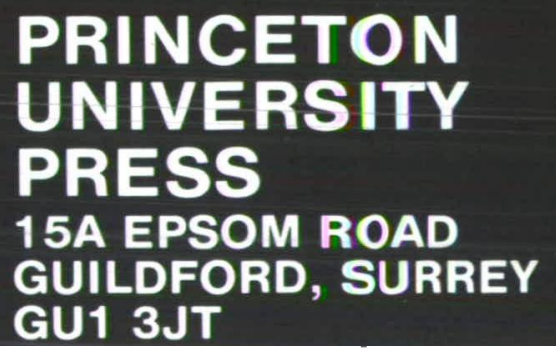




\section{PARASITOLOGY}




\section{PARASITOLOGY}

(Founded by G. H. F. Nuttall, F.R.S.)

EDITORS

D. W. T. CROMPTON and B. A. NEWTON

EDITORIAL ASSISTANT

M. ELISABETH PAINTER, Ph.D.

ADVISORY BOARD

L. G. GOODWIN, F.R.s. (Chairman)
R. ANDERSON
D. I. GIBSON
J. F. RYLEY
D. R. ARTHUR
L. P. JOYNER
G. SALT, F.R.S.
J. R. BAKER
C. R. KENNEDY
S. R. SMITHERS
J. BARRETT
ANN M. LACKIE
K. VICKERMAN
ELIZABETH U. CANNING
D. L. LEE*
D. WAKELIN
L. H. CHAPPELL
R. J. LINCOLN
P. F. V. WARD
S. COHEN, F.R.S.
J. LLEWELLYN
P. J. WHITFIELD
R. R. A. COOMBS, F.R.S.
S. H. P. MADDRELL
H. H. WILLI AMS
F. E. G. COX BRIDGET M. OGILVIE
R. A. WILSON
G. A. M. CROSS
M. ELA INE ROSE
C. A. WRIGHT
D. A. ERASMUS
J. H. ROSE

* Representing the British Society for Parasitology

V OLUME 81, 1980

CAMBRIDGE UNIVERSITY PRESS

CAMBRIDGE

$\begin{array}{rrr}\text { LONDON } & \text { NEW YORK } & \text { NEW ROCHELLE } \\ \text { MELBOURNE } & \text { SYDNEY }\end{array}$


Published by the Press Syndicate of the University of Cambridge

The Pitt Building, Trumpington Street, Cambridge CB2 1RP

32 East 57th Street, New York, N.Y. 10022

CC Cambridge University Press, 1980

Printed in Great Britain at the

University Press, Cambridge 


\section{CONTENTS \\ (All rights reserved)}

\section{Part 1 August 1980}

Smison, A. J. G. and Simthers, S. R. Characterization of the exposed carbohydrates on the surface membrane of adult Schistosoma mansoni by analysis of lectin binding .

Nawenya, B. Z. Altered lysophospholipase B responsiveness in lactating mice infected with intestinal nematode parasites .

LEE, D. L. and MARTIN, JEAN. The structure of the intestine of Nematodirus battus and changes during the course of an infection in lambs

Lawrence, S. B., Heath, D. D., Parmeter, S. N. and Osborn, P. J. Development of early larval stages of Taenia ovis in vitro using a cell monolayer

Fried, B., Fine, R. H. and Felter, Barbara, L. Growth, development and pairing of Leucochloridiomorpha constantiae (Trematoda) metacercariae on the chorio-allantois of chick embryos cultivated in vitro

Hiagns, J. C. Formation of the cyst wall and related changes in the structure of the tegument of Bucephalus haimeanus (Lacaze-Duthiers, 1854) during its metamorphosis from the cercarial to the metacercarial stage

Matthews, B. F. Cercaria vaullegeardi Pelseneer, 1906 (Digenea: Hemiuridae); the daughter sporocyst and emergence of the cercaria

KEARN, G. C. Light and gravity responses of the oncomiracidium of Entobdella soleae and their role in host location

Mircs, C. A. Temperature-dependent survival and reproduction within populations of the ectoparasitic digenean Transversotrema patialense on the fish host

Wharton, D. A. Studies on the function of the oxyurid egg-shell

Pittilo, R. M. and BALL, S. J. The ultrastructural development of the oocyst wall of Eimeria maxima

Dubey, J. P. and Whliams, C. S. F. Hammondia heydorni infection in sheep, goats, moose, dogs and coyotes

Young, A. S., Grootenhuis, J. G., Leitch, B. L. and Schein, E. The development of Theileria $=$ Cytauxzoon taurotragi (Martin and Brocklesby, 1960) from eland in its tick vector Rhipicephalus appendiculatus

Lewis, D., Purnell, R. E., Shaw, S. R. and Revington, J. P. The isolation and characterization of human and bovine strains of Babesia divergens from Drumnadrochit, Scotland

Slighter, R. G., Yarinsky, A., Drobeck, H. P. and Bamey, D. M. Activity of quinfamide against natural infections of Entamoeba criceti in hamsters: a new potent agent for intestinal amoebiasis .

BALL, S. J. Fine structure of the spores of Minchinia chitonis (Lankester, 1885) Labbé, 1896 (Sporozoa: Haplosporida), a parasite of the chiton, Lepidochitona cinereus 
McColm, A. A., Shakespeake, P. G. and Trigg, P. I. Analysis of proteins synthesized in vitro by the erythrocytic stages of Plasmodium knowlesi

McColm, A. A. and Trigg, P. I. Release of radio-isotope labelled antigens from Plasmodium knowlesi during merozoite re-invasion in vitro .

Knowles, G. and WaLLIKER, D. Variable expression of virulence in the rodent malaria parasite Plasmodium yoelii yoelii

Trends and Perspectives

Stephenson, Lani S. The contribution of Ascaris Lumbricoides to malnutrition in children

\section{Part 2 OCTOBer 1980}

Krtron, URIEL D. The pattern of infestation of the beach-hopper amphipod Orchestoidea corniculata, by a parasitic mite

Howard, R. J., Smith, Patricia M. and Mitchell, G. F. Characterization of surface proteins and glycoproteins on red blood cells from mice infected with haemosporidia: Babesia rodhaini infections of $\mathrm{BALB} / \mathrm{c}$ mice

Howard, R. J., Smith, Patricia M. and Mitchell, G. F. Characterization of surface proteins and glycoproteins on red blood cells from mice infected with haemosporidia: Plasmodium berghei infections of BALB/c mice .

Howard, R. J., Smith, Patricia M. and Mitchell, G. F. Characterization of surface proteins and glycoproteins on red blood cells from mice infected with haemosporidia: Plasmodium yoellii infections of BALB/c mice

Norton, C. C. and Joyner, L. P. Studies with Eimeria acervulina and E. mirati: pathogenicity and cross-immunity . . . . . . . .

LAwSON, J. RUTH and WILSON, R. A. Metabolic changes associated with the migration of the schistosomulum of Schistosoma mansoni in the mammal host

LAwson, J. Rutr and Wruson, R. A. The survival of the cercariae of Schistosoma mansoni in relation to water temperature and glycogen utilization

Coklho, P. M. Z., Gazzinelit, G. and Pellegrino, J. Schistosoma mansoni: host antigen occurrence on worms recovered from laboratory vertebrate animals

Long, E., Harrison, R., Bickle, Q., Bain, J., Nelson, G. and Doenhoff, M. Factors affecting the acquisition of resistance against Schistosoma mansoni in the mouse. The effect of varying the route and number of primary infections, and the correlation between the size of the primary infection and the degree of resistance that is acquired

De Meirelles, M. N. L., De Araujo Jorge, T. C. and De Souza, W. Interaction of epimastigote and trypomastigote forms of Trypanosoma cruzi with chicken macrophages in vitro

JAmes, DinaH M. and Born, G. V. R. Uptake of purine bases and nucleosides in African trypanosomes. 
Pappas, P. W. and Gamble, H. R. Membrane transport of aromatic amino acids

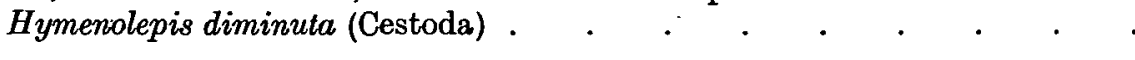

KeYMer, ANne E. The influence of Hymenolepis diminuta on the survival and fecundity of the intermediate host, Tribolium confusum . . . .

Parshad, V. R., Crompton, D. W. T. and Martin, Jean. Observations on the surface morphology of the ovarian balls of Moniliformis (Acanthocephala) .

Asaold, S. O. Morphology of the reproductive system of female Moniliformis dubius (Acanthocephala).

Trends and Perspectives

Wharton, David. Nematode egg-shells

\section{Part 3 December 1980}

Lanciani, Carmtne A. and Boyetr, J. M. Demonstrating parasitic water miteinduced mortality in natural host populations . . . . . . .

Youna, R. R., Anderson, N., Overend, D., Tweedie, R. L., Malafant, K. W. J. and Preston, G. A. N. The effect of temperature on times to hatching of eggs of the nematode Ostertagia circumcincta

Young, R. R., Nicholson, R. M., Tweedie, R. L. and Schuh, H.-J. Quantitative modelling and prediction of development times of the free-living stages of Ostertagia ostertagi under controlled and field conditions

Rose, J. H. and SmaLl, A. J. Observations on the development and survival of the free-living stages of Oesophagostomum dentatum both in their natural environments out-of-doors and under controlled conditions in the laboratory

Augustine, P. C. Effects of storage time and temperature on amylopectin levels and oocyst production of Eimeria meleagrimitis oocysts

ShIRLEY, M. W. Eimeria necatrix: the development and characteristics of an egg-adapted (attenuated) line

Cordingley, J. S. and TURner, M. J. Isolation and characterization of polysomes from Trypanosoma brucei

Crabtree, Jean E. and WiLson, R. A. Schistosoma mansoni: a scanning electron microscope study of the developing schistosomulum

Otubanjo, Olubunmi A. Schistosoma mansoni: the ultrastructure of the ducts of the male reproductive system

MARTLN, JeAN and LEe, D. L. Nematodirus battus: scanning electron microscope studies of the duodenal mucosa of infected lambs

Martin, JeAN and Lee, D. L. Observations on the structure of the male reproductive system and spermatogenesis of Nematodirus battus .

MARTIN, JEAN and LEE, D. L. Changes in the structure of the male reproductive system of Nematodirus battus during its rejection from lambs 
viii

Sharpe, M. J. Changes in the adenylate energy charge of Nematodirus dubius and Trichostrongylus colubriformis paralysed by levamisole in vivo

PAGE

Maki, JUN and Yanagisawa, Toshro. A comparison of the sites of acid phosphatase activity in an adult filaria, Setaria sp. and in some gastro-intestinal nematodes.

Vanoverschelde, R. and VAes, F. Studies on the life-cycle of Himasthla militaris (Trematoda: Echinostomatidae).

Trends and Perspectives

Tribe, H. T. Prospects for the biological control of plant-parasitic nematodes $\quad$. $\quad 619$ 


\section{PARASITOLOGY}

SUBSCRIPTIONS may be sent to any bookseller or subscription agent or direct to Cambridge University Press, P.O. Box 110, Cambridge CB2 3RL. Subscriptions in the U.S.A. and Canada should be sent to Cambridge University Press, 32 East 57th Street, New York, N.Y. 10022. All orders must be accompanied by payment. The subscription price of volumes 80 and 81,1980 , is $£ 26.00$ net (including postage) for a volume of three parts (US $\$ 75.00$ in the U.S.A. and Canada) payable in advance ( $£ 52.00$ or US $\$ 150.00$ per year); separate parts cost $£ 11.00$ net or US S32.0O each (plus postage).

BACK volumes. Vols. 1-39: Inquiries should be addressed to Wm. Dawson \& Sons Ltd, Cannon House, Folkestone, Kent. Vols. 40 onwards: quotations for parts still in print may be obtained from the Cambridge or New York offices of the Cambridge University Press.

COPYING. This journal is registered with the Copyright Clearance Center, 21 Congress Street, Salem, Mass. 01970. Organizations in the U.S.A. who are also registered with C.C.C. may therefore copy material (beyond the limits permitted by sections 107 and 108 of U.S. copyright law) subject to payment to C.C.C. of the per-copy fee indicated in the code on the first page of the article. This consent does not extend to multiple copying for promotional or commercial purposes.

IS I TEAR Service, 3501 Market Street, Philadelphia, Pennsylvania 19104, U.S.A., is authorized to supply single copies of separate articles for private use only.

FOR ALL OTHER USE, permission should be sought from the Cambridge or New York offices of the Cambridge University Press.

CLAIMS for missing issues can only be considered if made immediately after receipt of the subsequent issue.

ADVertising. Details of advertising in Paraaitology may be obtained from the publisher.

The previous part was published on 12 November 1980 


\title{
PARASITOLOGY
}

\author{
Volume 81, Part 3, December 1980
}

\section{CONTENTS}

Lanciani, Carmine A. and Boyett, J. M. Demonstrating parasitic water miteinduced mortality in natural host populations

PAGE

Young, R. R., Anderson, N., Overend, D., Tweedie, R. L., Malafant, K. W. J. and Preston, G. A. N. The effect of temperature on times to hatching of eggs of the nematode Ostertagia circumcincta

Young, R. R., Nicholson, R. M., Tweedie, R. L. and Schum, H. -J. Quantitative modelling and prediction of development times of the free-living stages of Ostertagia ostertagi under controlled and field conditions

Rose, J. H. and Small, A. J. Observations on the development and survival of the free-living stages of Oesophagostomum dentatum both in their natural environments out-of-doors and under controlled conditions in the laboratory

Augustine, P. C. Effects of storage time and temperature on amylopectin levels and oocyst production of Eimeria meleagrimitis oocysts

SHIRLEY, M. W. Eimeria necatrix: the development and characteristics of an eggadapted (attenuated line)

Cordingley, J.S. and Turner, M. J. Isolation and characterization of polysomes from Trypanosoma brucei

Crabtree, Jean E. and Wilson, R. A. Schistosoma monsoni: a scanning electron microscopic study of the developing schistosomulum

Otubanjo, Olubunmi A. Schistosoma mansoni: the ultrastructure of the ducts of the male reproductive system

Martin, Jean and Lee, D. L. Nematodirus battus: scanning electron microscope studies of the duodenal mucosa of infected lambs

Martin, JEAN and LEe, D. L. Observations on the structure of the male reproductive system and spermatogenesis of Nematodirus battus

MARtin, JEAN and LEe, D. L. Changes in the structure of the male reproductive system of Nematodirus battus during its rejection from lambs

SHARPE, M. J. Changes in the adenylate energy charge of Nematodirus dubius and Trichostrongylus colubriformis paralysed by levamisole in vivo

MAKI, JUA and Yanagisawa, Toshio. A comparison of the sites of acid phosphatase activity in an adult filaria, Setaria sp. and in some gastro-intestinal nematodes

Vanoverschelde, R. and VAes, F. Studies on the life-cycle of Himasthla militaris (Trematoda: Echinostomatidae)

Trends and Perspectives

Tribe, H. T. Prospects for the biological control of plant-parasitic nematodes

C Cambridge University Press 1980

The Pitt Building, Trumpington Street, Cambridge CB2 1RP

32 East 57th Street, New York, N.Y. 10022

Printed in Great Britain at the University Press, Cambridge 